\title{
Predictive value of bronchoalveolar lavage cell analysis in sarcoidosis
}

\author{
LEIF BJERMER, LEIF ROSENHALL, TORD ÅNGSTRÖM, ROGER HÄLLGREN
}

From the Departments of Pulmonary Medicine and Cytology, University Hospital, Umeå, and the Department of Internal Medicine, University Hospital, Uppsala, Sweden

ABSTRACT Patients with histopathologically proved sarcoidosis were studied serially by means of bronchoalveolar lavage, initially at the time of diagnosis and then six and 12 months later. Two years $\underset{\perp}{\infty}$ later they were evaluated by chest radiography and lung function tests and classified in terms of 0 recovery or progression over the previous two years. The recovery of lymphocytes and granulocytes $\rightarrow$ in lavage fluid was of limited prognostic value for persistent lung disease. In contrast, patients with $\rightarrow$ increased numbers of mast cells recovered by lavage were more likely to deteriorate. Significantly increased mast cell counts $(\geqslant 0.5 \%$ of total cells recovered) were seen in at least one lavage $\vec{\varphi}$ investigation in 15 of the 16 patients with more active and progressive disease, but in only eight of $23 \%$ patients with inactive disease $(p<0.001)$. A persistent increase of mast cells on serial measurement 0 occurred in nine of the 16 patients with active disease and in four of the 23 patients in whom the disease was inactive $(\mathrm{p}<0.02)$. The finding in the two subsequent lavages of lymphocytosis (lymphocytes $>30 \%$ of recovered cells) or neutrophilia (neutrophils $>15 \%$ ) combined with $\frac{2}{\circ}$ mastocytosis (mast cells $\geqslant 0.5 \%$ ) occurred in nine of the 16 patients with active disease but in no $\cong$ patients with inactive disease.

The technique of bronchoalveolar lavage has been used extensively since it was first introduced in the early $1970 s^{\prime}$ and the findings have contributed to the understanding of basic cellular mechanisms in various interstitial lung diseases. ${ }^{23}$ Several studies have shown good agreement between the findings in lavage fluid investigations and histopathology of lung biopsy specimens. ${ }^{45}$ In sarcoidosis the prominent finding in the lavage fluid is substantial lymphocytosis, mainly reflecting an increase of T lymphocytes of the OKT4/ Leu3 T helper cell phenotype. ${ }^{6}$ An increase of lavage T lymphocytes with a positive pulmonary gallium-67 scintigram has been claimed to be a sign of high intensity alveolitis, possibly predicting progressive lung disease. ${ }^{78}$ Other investigators have disputed the prognostic value of lavage fluid lymphocytosis, especially when conclusions are drawn from a single lavage sample. ${ }^{910}$ A persistent increase of lavage lymphocytes in serial measurements has been reported to be a more reliable estimate of disease activity." Increased numbers of polymorphonuclear neutrophils ${ }^{12}$ and mast cells ${ }^{1314}$ in lavage fluid from patients

Address for reprint requests: Dr Leif Bjermer, Department of Pulmonary Medicine, University Hospital, S-901 85 Umeả, Sweden. with sarcoidosis have been reported, by us and others, as possible indices of disease activity. Recently, however, the clinical value of lavage was questioned 0 and it was concluded that the value of cell counting in $\underset{x}{\vec{x}}$ lavage fluid still remains to be proved. ${ }^{10}$

The present study was designed in an attempt to assess the prognostic value of lymphocyte, macro- 8 phage, neutrophil, and mast cell counts in lavage fluid $₹$ from patients with sarcoidosis. Another aim was to 의 determine whether additional prognostic information $\rightarrow$ may be obtained by repeated lavages. In parallel to these lavage studies we investigated changes in lung $\tilde{\sim}$ function and radiographic appearances. The results suggest that the presence of mastocytosis in sequential 0 lavage fluid samples is a prognostically unfavourable $\underset{\omega}{N}$ finding.

\section{Methods}

We studied 45 patients ( 26 women, 19 men) with histopathologically proved sarcoidosis. Their mean $\stackrel{\vec{D}}{\bar{D}}$ age was 47 (range 28-74) years, and five were smokers. All were newly diagnosed and were admitted to our $\stackrel{\mathbb{Q}}{\mathscr{Q}}$ clinic for initial investigation.

The potential study population comprised a total of 53 patients. Five were excluded at the initial investi- 
gation because of extrathoracic symptoms (hypercalcaemia (2), myocardial sarcoidosis (1), aggressive uveitis (1), neurosarcoidosis (1)) requiring systemic corticosteroid treatment. One patient was excluded because of asthma, another because of mental disturbances that would have made evaluation of the clinical course difficult. One patient developed acute myeloid leukaemia. As controls we used 21 healthy, non-smoking volunteers with a mean age of 32 (range 21-57) years.

Patients were investigated initially and at follow up studies after six and 12 months by the performance of bronchoscopy with bronchoalveolar lavage, pulmonary function tests, and chest radiography. After two years the patients were evaluated according to symptoms, radiographic findings, and pulmonary function. The chest radiographs were reviewed by an experienced physician without knowledge of the data on lavage fluid or other clinical aspects of the patients. On the basis of radiographic and functional criteria at the two year follow up investigation patients were divided into the following subgroups: (1) Complete recovery $(\mathrm{CR})$, defined as patients $(\mathrm{n}=14)$ with no symptoms and with a normal chest radiograph and normal lung function. (2) Inactive disease with sequelae (IAS), defined as patients $(n=9)$ with radiographic improvement during the first year and with stationary radiolographic findings and lung function during the second year. They had persistent abnormalities, either radiographic infiltrates or a persistently low carbon monoxide transfer factor (TLCO) or vital capacity (VC)-that is, $<75 \%$ or $<80 \%$ respectively of predicted normal values ( $>2$ SD below the values from a normal reference population), or a reduction in TLCO or VC of over $15 \%$ below the initial values. (3) Persistently active disease (PA), defined as patients ( $\mathrm{n}$ $=16$ ) who showed signs of disease activity during the last year of the 2 year follow up period, either with appearance or increase of parenchymal infiltrates $(n=$ $12)$ or a reduction of VC or TLCO $>15 \%(n=11)$ compared with the findings at 12 months. (4) Rapidly progressive disease (RP): six of the patients developed symptoms and signs of rapidly progressive lung dis- ease soon after initial assessment, with increasing parenchymal infiltrates and substantial deterioration of lung function. According to local therapeutic practice corticosteroid treatment was initiated within six months of the initial evaluation in these subjects. Only the pretreatment lavage data on these patients were used for statistical analysis.

Vital capacity was measured by standard spirometry and transfer factor for carbon monoxide by the single breath technique. The values obtained were expressed as percentages of predicted normal values. ${ }^{1516}$ The following radiographic criteria were used for staging: stage 0 -no abnormality; stage Ibilateral hilar lymphadenopathy alone; stage IIbilateral hilar lymphadenopathy with parenchymal infiltrates; stage III-parenchymal infiltrates without hilar lymphadenopathy. The lung function and radiographic findings in our patients after a two year follow up are summarised in table 1.

Before bronchoscopy patients and controls were given subcutaneous atropine or scopalamine, usually combined with morphine or pethidine chloride. The upper respiratory tract was anaesthetised with lignocaine hydrochloride. A fibreoptic bronchoscope (Olympus BF IT or BF 4B2, Tokyo) was wedged in the segmental bronchus of the lingula and $240 \mathrm{ml}$ sterile Krebs-Ringer phosphate buffer, $\mathrm{pH} 7.3$ at $37^{\circ} \mathrm{C}$, was infused in boluses of $60 \mathrm{ml}$. The fluid was gently aspirated immediately after each instillation. The lavage fluid was kept on ice and filtered through a nylon filter (pore diameter $100 \mu \mathrm{m}$, Syntab Product AB, Malmö, Sweden). The cells were then collected by centrifugation at $400 \mathrm{~g}$ for 15 minutes. The cells were gently resuspended in balanced salt solution to a concentration of $10^{6}$ cells $/ \mathrm{ml}$, with epithelial cells excluded. Preparations for cytological studies were made in a cytocentrifuge (Cytospin Shandon, Southern Products Ltd, Runcorn, UK) with $5 \times 10^{4}$ nonepithelial cells a slide. The cytocentrifuge preparations were stained with May-Grünwald-Giemsa before differential counting. Mast cells were stained with acid toluidine blue and counterstained with Mayers acid haematoxylin. ${ }^{17}$ Lymphocytes, polymorphonuclear

Table 1 Radiological pulmonary findings and mean (SD) lung function values in patients with sarcoidosis at a two year follow up

\begin{tabular}{|c|c|c|c|c|c|c|}
\hline \multirow[b]{2}{*}{ Patient group } & \multicolumn{4}{|c|}{ Radiographic stage (n) } & \multirow[b]{2}{*}{ Vital capacity (\% pred) } & \multirow[b]{2}{*}{ Transfer factor (\% pred) } \\
\hline & 0 & $I$ & II & $I I I$ & & \\
\hline \multirow{3}{*}{$\begin{array}{l}\text { Complete recovery } \\
(n=14) \\
\text { Inactive disease with sequelae } \\
(n=19) \\
\text { Persistently active disease } \\
(n=16)\end{array}$} & 14 & 0 & 0 & 0 & $99(12)$ & $93(13)$ \\
\hline & 6 & 0 & 0 & 3 & $98(7)$ & $80(14)$ \\
\hline & 1 & 1 & 1 & 13 & $93(8)$ & $70(11)$ \\
\hline
\end{tabular}


cells, and macrophages were expressed as percentages of 200 non-epithelial cells counted. The relative counts of these cells were normally distributed. The numbers of mast cells in 10 visual fields with $\times 16$ magnification were expressed as percentages of all non-epithelial cells. The mast cell counts were log normally distributed.

The study was performed according to the Declaration of Helsinki and with free and informed consent of all volunteers and patients. For statistical comparison between the groups we used Wilcoxon's rank sum test. Chi-squared analysis was used for cross tabulation tests. Fisher's exact test was used when the expected frequency was less than 5 .

\section{Results}

\section{LAVAGE CELL ANALYSIS}

The lavage findings for the.four subgroups of patients and for the healthy controls are presented in table 2 . Lavage lymphocytosis was present in all subgroups of patients at the initial investigation. The degree of lymphocytosis was similar in the CR, IAS, and PA groups, but patients with rapidly progressive disease had significantly higher lymphocyte counts than the other groups of patients $(p<0.05)$. In the CR group the lymphocytosis was less at the follow up investigations. The recovery of alveolar marcrophages at the initial investigation was similar in all the subgroups of patients. In the CR group the macrophage counts were more normal at the follow up assessments as the lymphocyte counts declined. The recovery of neutrophils varied considerably between patients but no difference between subgroups were seen.

The number of mast cells recovered by lavage was the variable that best discriminated between the subgroups of patients (table 2). The percentages of mast cells recovered were in the order RP $>$ IAS $>$ CR $>$ healthy controls $(p<0.001)$. The lavage fluid mastocytosis had decreased in the CR and IAS groups at the 6 and 12 month follow up investigations but was unchanged in the PA group.
EVALUATION OF THE PROGNOSTIC VALUE OF ABNORMAL LAVAGE CELL FINDINGS

In an attempt to analyse the prognostic clinical value of abnormal lavage cell findings we defined significant $\frac{\overline{\bar{c}}}{\overline{\mathrm{n}}}$ lymphocytosis of the lavage fiuid as $>30 \%$ lym- $\vec{\varnothing}$ phocytes, neutrophilia as $>15 \%$ neutrophils, and $\stackrel{\circ}{\circ}$ mastocytosis as $\geqslant 0.5 \%$ of total cell counts. We also क analysed the sensitivity and specificity of single and $\overrightarrow{0}$ serial lavage cell counts in the prediction of deteriora- $\overrightarrow{-}$ tion to elucidate the validity of abnormal lavage cell findings in determining prognosis.

At the initial investigation most patients in all $\times$ subgroups had lavage fluid lymphocytosis (table 3). $\vec{\omega}$ Lavage fluid mastocytosis was seen in most patients from the PA group and in about one third of patientso from the CR and IAS groups. The six patients who developed rapidly progressive disease were only inves- - ? tigated once, before the start of steroid treatment; all $\vec{\nabla}$ six had lymphocytosis of the lavage fluid, five mas-을. tocytosis, and one neutrophilia (table 3).

We analysed the data to determine the prognostic $\oplus_{\infty}^{\circ}$ value of abnormal lavage cell findings on at least one ${ }^{\infty}$ occasion during the first year after diagnosis (table 3). Lavage fluid lymphocytosis was found at least once during this period in more than $60 \%$ of all patientso (patients in the RP group excluded) and it had noo prognostic value. Neither did lavage fluid neutrophilia $\triangle$ predict the outcome. In contrast, lavage mastocytosis $\vec{\circ}$ was associated with deterioration in lung disease. 3 However, lavage mastocytosis occurred at least once $?$ during the first year after diagnosis in 4/14 patients? with complete recovery suggesting a low degree of specificity for deterioration of lung function.

Finally, we assessed the prognostic value of abnor- $-x$ mal cell findings present at two subsequent investiga- $-\frac{-}{-}$ tions (table 3). Lavage fluid mastocytosis in serial. lavages was found in only one of the 14 patients in theo̊ CR group and in nine of the 16 patients in the PA group. Certain prognostic information was also으 provided by lavage fluid lymphocytosis. The combina- $\rightarrow$ tion of the lymphocytosis or neutrophilia of the lavageㅡ.

Table 2 Bronchoalveolar cell counts in lavage fluid from patients with sarcoidosis: median values and ranges obtained at the first investigation and six months and 12 months later

\begin{tabular}{|c|c|c|c|c|c|c|c|c|c|c|c|}
\hline \multirow{2}{*}{$\begin{array}{l}\text { Patient } \\
\text { group (n) } \\
\text { Complete recovery (14) }\end{array}$} & \multirow{2}{*}{$\begin{array}{l}\begin{array}{l}\text { Time } \\
\text { (months) }\end{array} \\
0 \\
6 \\
12\end{array}$} & \multicolumn{2}{|c|}{$\begin{array}{l}\text { Total cells } \\
\left(\times 10^{7}(l)\right.\end{array}$} & \multicolumn{2}{|c|}{$\begin{array}{l}\text { Macrophages } \\
(\%)\end{array}$} & \multicolumn{2}{|c|}{$\begin{array}{l}\text { Lymphocytes } \\
(\%)\end{array}$} & \multicolumn{2}{|c|}{$\begin{array}{l}\text { Neutrophils } \\
(\%)\end{array}$} & \multicolumn{2}{|c|}{$\begin{array}{l}\text { Mast cells } \\
(\%)\end{array}$} \\
\hline & & $\begin{array}{l}6 \cdot 7 \\
5 \cdot 4 \\
9 \cdot 0\end{array}$ & $\begin{array}{l}3 \cdot 0-23 \cdot 0 \\
3 \cdot 0-41 \cdot 6 \\
2 \cdot 4-32 \cdot 6\end{array}$ & $\begin{array}{l}52 \\
71 \\
84\end{array}$ & $\begin{array}{l}14-91 \\
22-88 \\
15-95\end{array}$ & $\begin{array}{l}44 \\
24 \\
11\end{array}$ & $\begin{array}{r}8-85 \\
10-61 \\
5-83\end{array}$ & $\begin{array}{l}1 \\
2 \\
3\end{array}$ & $\begin{array}{l}0-5 \\
0-18 \\
0-18\end{array}$ & $\begin{array}{l}0.16 \\
0.11 \\
0.07\end{array}$ & $\begin{array}{l}0.00-5 \cdot 37 \\
0.03-1.09 \\
0.00-0.46\end{array}$ \\
\hline $\begin{array}{l}\text { Inactive disease with } \\
\text { sequelae (9) }\end{array}$ & $\begin{array}{r}0 \\
6 \\
12\end{array}$ & $\begin{array}{l}7 \cdot 5 \\
8 \cdot 4 \\
6 \cdot 0\end{array}$ & $\begin{array}{l}2 \cdot 0-13 \cdot 0 \\
2 \cdot 6-12 \cdot 3 \\
3 \cdot 4-10 \cdot 8\end{array}$ & $\begin{array}{l}67 \\
70 \\
68\end{array}$ & $\begin{array}{l}24-90 \\
41-90 \\
40-93\end{array}$ & $\begin{array}{l}31 \\
36 \\
30\end{array}$ & $\begin{array}{l}7-55 \\
9-56 \\
7-59\end{array}$ & $\begin{array}{l}1 \\
1 \\
2\end{array}$ & $\begin{array}{l}0-1 \\
0-4 \\
0-4 \\
0-4\end{array}$ & $\begin{array}{l}0.40 \\
0.34 \\
0.23\end{array}$ & $\begin{array}{l}0.03-4.63 \\
0.03-1.89 \\
0.00-2 \cdot 23\end{array}$ \\
\hline Persistently active disease (16) & $\begin{array}{r}0 \\
6 \\
12\end{array}$ & $\begin{array}{l}9 \cdot 0 \\
7 \cdot 0 \\
5 \cdot 0\end{array}$ & $\begin{array}{l}2 \cdot 0-27 \cdot 0 \\
2 \cdot 0-18 \cdot 3 \\
1 \cdot 6-14 \cdot 8\end{array}$ & $\begin{array}{l}51 \\
39 \\
53\end{array}$ & $\begin{array}{l}19-87 \\
10-88 \\
24-76\end{array}$ & $\begin{array}{l}46 \\
56 \\
44\end{array}$ & $\begin{array}{r}10-77 \\
12-87 \\
5-72\end{array}$ & $\begin{array}{l}1 \\
1 \\
2\end{array}$ & $\begin{array}{l}0-24 \\
0-54 \\
0-35\end{array}$ & $\begin{array}{l}0.63 \\
0.63 \\
0.62\end{array}$ & $\begin{array}{l}0.03-9.43 \\
0.06-3.77 \\
0.03-4.00\end{array}$ \\
\hline $\begin{array}{l}\text { Rapidly progressive disease (6) } \\
\text { Healthy controls (21) }\end{array}$ & 0 & $\begin{array}{r}13.0 \\
6.4\end{array}$ & $\begin{array}{l}5 \cdot 0-20 \cdot 0 \\
2 \cdot 4-10 \cdot 0\end{array}$ & $\begin{array}{l}33 \\
92\end{array}$ & $\begin{array}{l}21-42 \\
68-98\end{array}$ & $\begin{array}{r}63 \\
6\end{array}$ & $\begin{array}{r}45-78 \\
2-30\end{array}$ & 1 & $\begin{array}{l}0-18 \\
0-5\end{array}$ & $\begin{array}{l}0.93 \\
0.00\end{array}$ & $\begin{array}{l}0.06-8.29 \\
0.00-0.02\end{array}$ \\
\hline
\end{tabular}


Table 3 Frequency of abnormal lavage cell findings in patients with sarcoidosis (classified according to outcome after two years): (A) at initial investigation, (B) once or more during the first year after diagnosis, and (C) at two subsequent invèstigations during the first year

\begin{tabular}{|c|c|c|c|c|c|}
\hline & $\begin{array}{l}\text { Complete recovery } \\
(n=14)\end{array}$ & $\begin{array}{l}\text { Incomplete recovery } \\
(n=9)\end{array}$ & $\begin{array}{l}\text { Persistently active } \\
\text { disease }(n=16)\end{array}$ & $\begin{array}{l}\text { Rapidly progressive } \\
\text { disease }(n=6)\end{array}$ & $p^{*}$ \\
\hline $\begin{array}{l}\text { A Abnormal lavage cell findi } \\
\text { Lymphocytes }>30 \% \\
\text { Neutrophils }>15 \% \\
\text { Mast cells } \geqslant 0.5 \%\end{array}$ & $\begin{array}{l}\text { igs at the initial investig } \\
10(71) \\
0 \\
3(21)\end{array}$ & $\begin{array}{l}\text { ion }(\mathrm{No}(\%) \text { of patient } \\
7(78) \\
0 \\
3(33)\end{array}$ & $\begin{array}{l}12(75) \\
1(6) \\
9(56)\end{array}$ & $\begin{array}{l}6(100) \\
1(17) \\
5(83)\end{array}$ & $\begin{array}{l}\text { NS } \\
\text { NS } \\
\text { NS }\end{array}$ \\
\hline $\begin{array}{l}B \text { Abnormal lavage cell findi } \\
\text { Lymphocytes }>30 \% \\
\text { Neutrophils }>15 \% \\
\text { Mast cells } \geqslant 0.5 \%\end{array}$ & $\begin{array}{l}\text { ges once or more during } \\
10(71) \\
2(14) \\
4(29)\end{array}$ & $\begin{array}{l}\text { first year after diagnos } \\
6(66) \\
0 \\
4(49)\end{array}$ & $\begin{array}{l}\text { is (No (\%) of patient } \\
14(88) \\
4(25) \\
15(94)\end{array}$ & & $\begin{array}{l}\text { NS } \\
\text { NS } \\
<0.001\end{array}$ \\
\hline $\begin{array}{l}C \text { Abnormal lavage cell findi } \\
\text { Lymphocytes }>30 \% \\
\text { Neutrophils }>15 \% \\
\text { Mast cells } \geqslant 0.5 \%\end{array}$ & $\begin{array}{l}\text { igs at two subsequent } \\
3(21) \\
1(17) \\
1(7)\end{array}$ & $\begin{array}{l}\text { stigations during the fir } \\
3(33) \\
0 \\
3(33)\end{array}$ & $\begin{array}{l}\text { year after diagnosis } \\
9(64) \\
1(6) \\
9(64)\end{array}$ & (\%) of patients) & $\begin{array}{l}<0.05 \\
\text { NS } \\
<0.02\end{array}$ \\
\hline
\end{tabular}

*Comparison of complete recovery with incomplete recovery and persistently active disease groups (Fisher's exact test).

flüid with pulmonary mastocytosis at two subsequent measurements had the highest specificity $(100 \%)$ for the prediction of deterioration.

\section{Discussion}

The recovery of lymphocytes and granulocytes during bronchoalveolar lavage in our hands has proved to be of limited prognostic value for lung disease in sarcoidosis. We observed, however, that lavage fluid lymphocytosis that was still present at two subsequent investigations tended to correlate with deterioration of lung function, which might support the conclusions of those who have suggested that lavage fluid lymphocytosis, especially when found in serial measurements, is of clinical value ${ }^{7811}$ Possibly $T$ cell subpopulation studies might have provided different information. Although an increased recovery of neutrophils in lavage fluid has been proposed as reflecting more active sarcoidosis, ${ }^{18}$ we were unable to relate neutrophilia to aggressive disease. This study did, however, support our preliminary observation that an increase of mast cells in the lavage fluid seems to be related to more active sarcoidosis of the lungs. ${ }^{13}$

In previous studies of lavage fluid from patients with sarcoidosis mast cells have accounted for $0 \cdot 2-1: 4 \%$ of the total cells recovered. ${ }^{9}$ Haslam et a ${ }^{19}$ found a lower proportion of mast cells, less than $0.5 \%$ in all 40 patients. In our study the significant increase of mast cells in lavage fluid - that is, $\geqslant 0.5 \%$ of the total cells recovered-was a frequent finding that was observed in about half the patients in at least one lavage fluid out of three during the first year of the disease. Thus finding mastocytosis in a single lavage seems to be of limited value as a prognostic sign. The specificity of lavage fluid mastocytosis as an indicator of persistently active lung disease increased, however, when two subsequent lavages with increased mast cells were recorded. The combination in two subsequent lavages of mastocytosis and lymphocytosis ( $>30 \%$ of total cells recovered) or mastocytosis and neutrophilia ( $>15 \%$ of total cells recovered) was seen in nine of the 16 patients with persistently active disease, but in none of the 14 patients with complete recovery or the nine with inactive disease with sequelae. The possible link between lavage fluid mastocytosis and sarcoidosis of the lung was further supported by our observation that the largest number of mast cells at the initial investigation was found in those patients who had rapidly progressive lung disease requiring corticosteroid treatment shortly after the diagnosis of sarcoidosis.

The present observation that an increase in mast cell numbers is related to the likelihood of progression of lung disease merits further study of the possible pathophysiological role of the mast cell. Previous investigators have reported that mast cells appear in increased numbers in the lung tissue of patients with fibrotic lung diseases. ${ }^{20}$ It has also been observed in animal experiments that the number of lung mast cells increases with increasing severity of pulmonary fibrosis. ${ }^{21} 22$ We ourselves have recently reported that bronchoalveolar mastocytosis in sarcoidosis and other interstitial granulomatous lung diseases is closely linked to biochemical signs of fibroblast activation. ${ }^{2324}$ Furthermore, histamine stimulates fibroblast proliferation in vitro and mast cell degranulation in vivo is associated with $\mathrm{H}_{2}$ receptor dependent proliferation of fibroblast like cells. ${ }^{2526}$ Thus previous observations and the present study suggest that mast cells and mast cell activation may be related to lung tissue damage. The link between recruitment of mast cells to the lung and the established cellular immune events in the lung in sarcoidosis is not clear. It is, 
however, apparent that $\mathrm{T}$ lymphocytes have a role in mast cell proliferation ${ }^{26}$ and modulate mast cell function. ${ }^{2627}$

We would like to thank the department of cytology, University Hospital, Umeå, for valuable help with the cytological preparations. The study was supported by grants from the Swedish Association Against Chest and Lung Diseases and the Medical Research Council.

\section{References}

1 Reynolds HY, Newball HH. Analysis of proteins and respiratory cells obtained from human lung by bronchial lavage. J Lab Clin Med 1974;84:559-73.

2 Rossi GA. Bronchoalveolar lavage in the investigation of disorders of the lower respiratory tract. Eur J Respir Dis 1986;69:293-315.

3 Daniele RP, Elias JA, Epstein PE, et al. Bronchoalveolar lavage: role in the pathogenesis, diagnosis, and management of interstitial disease. Ann Intern Med 1985; 102:93-108.

4 Semenzato G, Ghilosi M, Ossi E, et al. Bronchoalveolar lavage and lung histology: comparative analysis of inflammatory and immuno-competent cells in patients with sarcoidosis and hypersensitivity pneumonitis. $\mathrm{Am}$ Rev Respir Dis 1985;132:400-4.

5 Hunninghake GW, Gadek JE, Young RC. Maintenance of granuloma formation in pulmonary sarcoidosis by $\mathrm{T}$ lymphocytes within the lung. $N$ Engl J Med 1980; 302:594-8.

6 Hunninghake GW, Crystal RG. Pulmonary sarcoidosis: a disorder mediated by excess helper $\mathrm{T}$ lymphocyte activity at sites of disease activity. $N$ Engl $J$ Med 1981;305:429-34.

7 Crystal RG, Hunninghake GW, Gadek JE, et al. The pathogenesis of sarcoidosis. In: Chretien J, Marsac J, Saltiel JC, eds. Sarcoidosis and other granulomatous disorders. Paris: Pergamon Press, 1983:13-35.

8 Costabel U, Bross KJ, Nilles A, et al. Predictive value of bronchoalveolar $\mathrm{T}$ cell subsets for the course of pulmonary sarcoidosis. Ann NY Acad Sci 1986;465: 418-26.

9 Buchalter W, Jackson AL, Chandler D, et al. Bronchoalveolar lavage cell analysis in sarcoidosis: a comparison of lymphocyte counts and clinical course. Ann NY Acad Sci 1986;465:678-84.

10 Turner-Warwick M, McAllister W, Lawrence R, et al. Corticosteroid treatment in sarcoidosis: do serial lavage lymphocyte counts, serum angiotensin converting enzyme measurements and gallium-67 scans help management? Thorax 1986;41:903-13.

11 Israel-Biet D, Venet A, Chretien J. Persistent high alveolar lymphocytosis as a predictive criterion of chronic pulmonary sarcoidosis. Ann N Y Acad Sci 1986; 465:395-406.

12 Zavala DC, Hunninghake GW. Lung lavage. In: Flenley? $\mathrm{D}$, Petty $\mathrm{T}$, eds. Recent advances in respiratory medicine. 흐 No 3. Edinburgh: Churchill Livingstone, 1983:20-32. $\overline{\frac{\omega}{7}}$

13 Bjermer L, Bäck O, Roos G, Thunell M. Mast cells andळ lysozyme positive macrophages in bronchoalveolar lavage in patients with sarcoidosis: valuable prognostics and activity marking parameters of disease? Acta Med Scand 1986;220:161-6.

14 Flint KC, Leung KBP, Hudspith BN, Brostoff J, Pearceç FL, Geraint-James D, Johnson N Mcl. Bronchoalveolar mast cells in sarcoidosis: increased numbers and accentuation of mediator release. Thorax 1986; 41:94-9.

15 Berglund E, Birath G, Bjure J, et al. Spirometric studies in normal subjects. Acta Med Scand 1963;173:185-206.

16 Hinshaw HC, Murray JF, eds. Disease of the chest.o Philadelphia: WB Saunders, 1980:75-144.

17 Strobel S, Miller HRP, Ferguson A. Human intestina mucosal mast cells: evaluation of fixation and stainingo techniques. J Clin Pathol 1981;34:851-8.

18 Lin YH, Haslam PL, Turner-Warwick M. Chronice pulmonary sarcoidosis: relationship between lavage celpo counts, chest radiograph, and results of standard lung function tests. Thorax 1985;40:501-7.

19 Haslam PL, Dewar A, Butchers P, Primett ZS, NewmanTaylor A, Turner-Warwick M. Mast cells, atypica lymphocytes, and neutrophils in bronchoalveola lavage in extrinsic allergic alveolitis. Am Rev Respir Dis 1987;135:35-47.

20 Kawanami O, Forram VJ, Fulmer JD, et al. Ultrastruc-윽 ture of pulmonary mast cells in patients with fibrotic lung disorders. Lab Invest 1979;40:717-34.

21 Goto T, Befus D, Low R, Bienenstock J. Mast celf heterogeneity and hyperplasia in bleomycin-induced pulmonary fibrosis of rats. Am Rev Respir Dis 1984;130:797-802.

22 Watanabe $\mathrm{S}$, Watanabe $\mathrm{K}$, Ohishi $\mathrm{T}$, et al. Mast cells ino the rat alveolar septa undergoing fibrosis after ionizing irradiation. Lab Invest 1974;31:555-67.

23 Bjermer L, Engström-Laurent A, Thunell M, Hällgren R Hyaluronic acid in bronchoalveolar lavage fluid in patients with sarcoidosis: relation to lavage mast cells? Thorax 1987;42:933-8.

24 Bjermer L, Engström-Laurent A, Lundgren R, Rosenhale. L, Hällgren R. Bronchoalveolar mastocytosis in far $N$ mer's lung is related to disease activity and signs of fibroblast activation. Arch Intern Med (in press)

25 Russel JD, Russel SB, Trupin KM. The effect on the growth of cultured fibroblasts isolated from normal and6 keloid tissue. J Cell Physiol 1977;93:389-94.

26 Claman HN. Mast cells, T cells and fibrosis. Immuno Today 1985;6:192-5.

27 Bienenstock J, Befus D. Mast cells in host defense: Leukocyte and Host Defense 1986:347-55. 